\title{
Yield and water use efficiency of cowpea under water deficit
}

\author{
Paulo J. O. P. Souza ${ }^{1,3}$, Thaynara F. Ramos ${ }^{1}$, Lucilene de C. S. Fiel ${ }^{1}$, \\ Vivian D. da S. Farias ${ }^{2}$, Denis de P. Sousa ${ }^{3} \&$ Hildo G. G. C. Nunes ${ }^{3}$ \\ ${ }^{1}$ Universidade Federal Rural da Amazônia/Instituto Socioambiental e dos Recursos Hídricos. Belém, PA. E-mail: paulo.jorge@ufra.edu.br (Corresponding \\ author) - ORCID: 0000-0003-4748-1502; thaynara_ramos@yahoo.com.br - ORCID: 0000-0002-0173-8344; lenefiel@hotmail.com - ORCID: 0000- \\ 0001-9232-3189 \\ ${ }^{2}$ Universidade Federal do Oeste do Pará/Campus Juruti. Juruti, PA. E-mail: viviandielly19@yahoo.com.br - ORCID: 0000-0003-0395-7839 \\ ${ }^{3}$ Universidade Federal Rural da Amazônia/Programa de Pós-Graduação em Agronomia. Belém, PA. E-mail: denisdepinho@agronomo.eng.br - ORCID: \\ 0000-0001-5300-6383; garibalde13@gmail.com - ORCID: 0000-0003-4072-003X
}

\begin{abstract}
The state of Pará is the main regional producer of cowpea, but its yield is still low compared to other states of the Northern region such as Amazonas and Tocantins, due to the management adopted and the water regime during the cycle, since its cultivation is conducted on a rainfed basis. The objective of this study was to evaluate how water deficit imposed during reproductive stage interferes in the yield of cowpea and in its water use efficiency under the climatic conditions of Castanhal, Pará, Brazil, for agricultural planning purposes. The experiment was carried out in Castanhal, northeastern region of the Pará state during the dry season of 2014, 2015 and 2016. The experimental design was randomized blocks with six blocks and four treatments, corresponding to different irrigation depths in the reproductive stage, defined as 100, 50, 25 and $0 \%$ of the crop evapotranspiration. Water use efficiency (WUE) was determined by the ratio between total grain yield and total water used in each treatment. Maximum water availability led to an average increase in yield of 58\% compared to the treatment without irrigation. Water depths below $260 \mathrm{~mm}$ limited yield to values lower than $1,000 \mathrm{~kg} \mathrm{ha}^{-1}$. The cultivar adopted had WUE of $4.63 \mathrm{~kg} \mathrm{ha}^{-1} \mathrm{~mm}^{-1}$, in response to the higher levels of water supply, but showed WUE of $4.31 \mathrm{~kg} \mathrm{ha}^{-1} \mathrm{~mm}^{-1}$ under water depth of $50 \%$ of water demand.
\end{abstract}

Key words: water deficit, water demand, irrigation management

\section{Produtividade e eficiência do uso da água do feijão-caupi sob deficiência hídrica}

RESUMO: O estado do Pará é o maior produtor regional de feijão caupi, mas a produtividade alcançada ainda fica abaixo de outros estados da região Norte como Amazonas e Tocantins, devido ao manejo adotado e ao regime hídrico durante a safra, uma vez que seu cultivo é realizado em regime de sequeiro. Objetivou-se neste trabalho avaliar como a deficiência hídrica imposta durante a fase reprodutiva interfere na produtividade e na eficiência do uso da água pelo feijão-caupi nas condições climáticas de Castanhal, Pará, para fins de planejamento agrícola. O experimento foi realizado no município de Castanhal, região nordeste do estado do Pará durante o período menos chuvoso dos anos 2014, 2015 e de 2016. Adotou-se o delineamento experimental em blocos ao acaso com 6 blocos e quatro tratamentos, correspondentes a diferentes lâminas de irrigação na fase reprodutiva, definidas como 100, 50, 25 e 0\% da evapotranspiração da cultura. A eficiência do uso da água (EUA) foi determinada pela razão entre a produtividade de grãos e a lâmina total de água utilizada em cada tratamento. A máxima disponibilidade hídrica proporcionou aumento médio na produtividade de $58 \%$ comparado ao tratamento sem irrigação. Lâminas de água menores que $260 \mathrm{~mm}$ limitaram a produtividade a valores abaixo de $1.000 \mathrm{~kg} \mathrm{ha}^{-1}$. A cultivar adotada apresentou eficiência no uso da água de $4,63 \mathrm{~kg} \mathrm{ha}^{-1} \mathrm{~mm}^{-1}$, para as maiores ofertas hídricas, mas apresentou EUA de 4,31 $\mathrm{kg} \mathrm{ha}^{-1} \mathrm{~mm}^{-1}$ com a lâmina de $50 \%$ da demanda hídrica.

Palavras-chave: déficit hídrico, consumo hídrico, manejo de irrigação 


\section{INTRODUCTION}

Cowpea (Vigna unguiculata L. Walp.) is a crop of great economic and social importance for the Brazilian population (Calvet et al., 2013) and its production is concentrated in the North, Northeast and Midwest regions of the country (Freire Filho et al., 2011), being greatly influenced by the water deficit and irregular rainfall distribution, especially in Northeast Brazil (Barros et al., 2013).

In the North region, the Pará state is a leader in both area and production, but its average yield $\left(850 \mathrm{~kg} \mathrm{ha}^{-1}\right)$ is still low compared to those of other states, such as Amazonas $\left(954 \mathrm{~kg} \mathrm{ha}^{-1}\right)$ and Tocantins $\left(1.168 \mathrm{~kg} \mathrm{ha}^{-1}\right)$, and to that obtained in the Midwest region (960 $\mathrm{kg} \mathrm{ha}^{-1}$ ) (Freire Filho et al., 2011). Due to the high rainfall level in this region, cowpea cultivation is commonly conducted in the period of transition from the rainy to the least rainy period, and under rainfed conditions, which limits the production to a single season due to the increase of water deficit from July (Freire Filho et al., 2009).

Souza et al. (2017) found yields of cowpea, cultivar BR3 Tracuateua in Northeastern Pará, ranging from 1,115 and $1,396 \mathrm{~kg} \mathrm{ha}^{-1}$ when grown under low water deficit in the reproductive stage, similar to the values observed by Freire Filho et al. (2009) for the same cultivar (BR3 Tracuateua) and region, and by Oliveira et al. (2011) for the cultivar BRS Novaera in the Roraima state.

Water deficit normally induces stomatal closure in crops (Souza et al., 2017), causing reduction of transpiration and photosynthesis, and consequently in dry matter production, although the levels of tolerance change for different plant species (Scalon et al., 2011). Silva et al. (2010) found for the cultivar BRS Xiquexique reductions of 94, 96 and $80 \%$ in stomatal conductance, net photosynthesis and water use efficiency, respectively, when under water replacement corresponding to $25 \%$ of its requirement during the vegetative stage.

Cowpea is considered as a species adapted to drought, but its response to water deficit conditions varies according to cultivar, time of exposure and region of study (Nascimento et al., 2011). Very few studies with this approach were conducted in this region of the country and, therefore, the present study aimed to analyze the influence of water availability during reproductive stage as a function of different levels of water deficit on the yield and water use efficiency of cowpea in Northeastern Pará for agricultural planning purposes.

\section{Material AMethods}

The experiment was conducted in Northern Pará state, at the School Farm of the Federal Rural University of Amazônia (UFRA) in the municipality of Castanhal (1 ${ }^{\circ} 19^{\prime} 07^{\prime \prime} \mathrm{S}$ and $47^{\circ}$ 57 ' $38^{\prime \prime} \mathrm{W}, 35 \mathrm{~m}$ ). Three experiments were conducted from September 9 to November 11 in 2014, from September 23 to November 26 in 2015, and from September 17 to November 18 in 2016.

The experimental field of the $1^{\text {st }}$ year was located in a 1.5 ha area cultivated with cowpea, cultivar BR3-Tracuateua. In the other years, the experiment was conducted in an adjacent area with $0.5 \mathrm{ha}\left(1^{\circ} 19^{\prime} 14^{\prime \prime} \mathrm{S}\right.$ and $47^{\circ} 57^{\prime} 45^{\prime \prime} \mathrm{W}, 41 \mathrm{~m}$ ).
Conventional tillage with plowing and harrowing was used to control weeds, decompact the soil and provide satisfactory conditions for planting, seed germination and crop development.

Sowing density was determined by the germination test, conducted with a mechanical sowing machine, at spacing of $0.5 \mathrm{~m}$ between rows and $0.1 \mathrm{~m}$ between plants. At 10 days after sowing (DAS), thinning was performed to leave 10 plants per linear meter, maintaining a density of 200,000 plants ha- ${ }^{-1}$. Prior to sowing, seeds were adequately prepared with fungicide and insecticide, and weeds and pests were controlled according to the need. Fertilization was performed at sowing and as topdressing at $10 \mathrm{DAS}$. The results of soil chemical and physical analyses are presented in Table 1 . Soil texture and physical characteristics were obtained at the Laboratory of Soil of EMBRAPA Eastern Amazon, determined in undisturbed soil samples using Richards' pressure plate apparatus to find the permanent wilting point (PWP) and tension table for field capacity (FC) and saturation, considering pressures of 1,500, 10 and $0 \mathrm{kPa}$, respectively (Teixeira \& Behring, 2017).

The experiment was conducted in a randomized block design with six blocks and four treatments, which corresponded to water depths equivalent to $100 \% \mathrm{ETc}$ (T1); $50 \% \mathrm{ETc}$ (T2); $25 \% \mathrm{ETc}$ (T3) and $0 \% \mathrm{ETc}$ (T4), from the beginning of the reproductive stage (R5), approximately at 36 DAS. In 2016, movable covers (polypropylene) were mounted during the rain events occurred in the reproductive stage in order to prevent water from entering the treatment $0 \% \mathrm{ETc}$, and removed after the event.

Cowpea development stages were observed using the scale of Gepts \& Fernández, described by Farias et al. (2015), based on daily monitoring of three 1-m-long rows containing 10 plants in each treatment. The stages were identified as follows: V0 (germination); V1 (cotyledons above the soil); V2 (cotyledon leaves expanded) V3 ( $1^{\text {st }}$ trifoliate leaf open); V4 ( $3^{\text {rd }}$ trifoliate leaf open); R5 ( $1^{\text {st }}$ flower bud); R6 (anthesis of $1^{\text {st }}$ flower); R7 ( $1^{\text {st }}$ pod); R8 (grain filling); R9 (physiological maturity).

The irrigation depth was determined from the calculation of reference evapotranspiration by the Penman-Monteith method (Allen et al., 2011) with data obtained from the automatic

Table 1. Chemical and physical analysis of Yellow Latosol, referring to the soil from the $1^{\text {st }}$ to the $3^{\text {rd }}$ experiment

\begin{tabular}{|c|c|c|c|}
\hline \multirow{2}{*}{ Characteristcs } & \multicolumn{3}{|c|}{ Samples $(0$ to $20 \mathrm{~cm}$ ) } \\
\hline & 2014 & 2015 & 2016 \\
\hline $\mathrm{pH}\left(\mathrm{H}_{2} \mathrm{O}\right)$ & 4.60 & 4.90 & 3.70 \\
\hline $\mathrm{N}(\%)$ & 0.06 & 0.05 & 0 \\
\hline$P\left(\mathrm{mg} \mathrm{dm}^{-3}\right)$ & 10 & 2 & 20 \\
\hline $\mathrm{K}^{+}\left(\mathrm{cmol}_{\mathrm{c}} \mathrm{dm}^{-3}\right)$ & 0.023 & 0.06 & 0.08 \\
\hline $\mathrm{Ca}^{2+}\left(\mathrm{cmol}_{\mathrm{c}} \mathrm{dm}^{-3}\right)$ & 1.40 & 1.43 & 1 \\
\hline $\mathrm{Mg}\left(\mathrm{cmol}_{\mathrm{c}} \mathrm{dm}^{-3}\right)^{\prime}$ & 0.70 & 0.20 & 0.20 \\
\hline $\mathrm{Al}^{+}\left(\mathrm{cmol}_{\mathrm{C}} \mathrm{dm}^{-3}\right)$ & 0.40 & 0.80 & 0.60 \\
\hline Sand $\left(\mathrm{g} \mathrm{kg}^{-1}\right)$ & 886 & 835 & 835 \\
\hline Silt $\left(\mathrm{g} \mathrm{kg}^{-1}\right)$ & 63 & 125 & 125 \\
\hline Clay $\left(\mathrm{g} \mathrm{kg}^{-1}\right)$ & 51 & 40 & 40 \\
\hline Soil density $\left(\mathrm{g} \mathrm{cm}^{-3}\right)$ & 1.46 & 1.56 & 1.56 \\
\hline Field capacity $(\mathrm{FC})\left(\mathrm{m}^{3} \mathrm{~m}^{-3}\right)$ & 0.22 & 0.20 & 0.20 \\
\hline Permanent wilting point (PWP) $\left(\mathrm{m}^{3} \mathrm{~m}^{-3}\right)$ & 0.07 & 0.11 & 0.11 \\
\hline Easily available water (EAW)* & 0.15 & 0.17 & 0.17 \\
\hline
\end{tabular}

*Obtained to a effective root deep of $25 \mathrm{~cm}$ and sensibility factor of 0.4 
meteorological station of the National Institute of Meteorology (INMET), installed $2 \mathrm{~km}$ away from the experiment, and then multiplied by the crop coefficients (Kc) suggested by Bastos et al. (2008) to obtain crop evapotranspiration (ETc), corresponding to 0.8 in the initial stage, from 0.8 to 1.1 in the development stage, from 1.1 to 1.4 in the establishment stage and from 1.4 to 0.3 in the final stage.

Every day during the entire vegetative stage, all treatments received the same water depth, corresponding to a replacement of $100 \%$ ETc (irrigation + rain), for the establishment and standardization of the crop and to keep the treatments close to field capacity. Irrigation treatments began in the reproductive stage (R5) and extended until the beginning of the grain maturation stage (R9).

A drip irrigation system was used with flow rate of $1.03 \mathrm{~L}$ $\mathrm{h}^{-1}$ under service pressure of 5 m.w.c. and emitters spaced by 20 $\mathrm{cm}$. System performance evaluation indicated a Christiansen's uniformity coefficient (CUC) of $94 \%$ and an irrigation application efficiency (Ea) of $81 \%$.

The meteorological conditions during the experiment were recorded by an automatic micrometeorological station installed in the experimental area, equipped with sensors of temperature and relative humidity (Thermohygrometer, Vaisala, HMP45a), rainfall (Rain Gauge, Campbell Sci., TB4), wind speed and direction (Cup anemometer vector, Campbell Sci., R.M. Young 03002), global solar radiation (Pyranometer, Kipp \& Zonen, CMP3) and soil water volumetric content (TDR, Campbell Sci., CS616), all connected to a datalogger (Campbell Sci. CR10x) programmed to take readings every $10 \mathrm{~s}$ and record means/ totals every $10 \mathrm{~min}$, and then converted to daily scale.

The water deficits imposed by the treatments were quantified based on the sequential climatological water balance, according to Carvalho et al. (2011), considering the available water capacity (AWC) of the experimental area and the effective depth of the root system visually observed in the field (Souza et al., 2017). Water deficit was obtained by the difference between daily ETm and the ETr resulting from the entry of water (rain + irrigation) and based on the AWC.

Yield was measured at 63 DAS in 2014, 65 DAS in 2015 and 68 DAS in 2016, when $90 \%$ of the plants reached the R9 phenological stage. Harvest was carried out in two planting rows previously separated in each treatment, from where three $1-\mathrm{m}^{2}$ samples were collected, represented by $2-\mathrm{m}$-long rows, which were dried for $72 \mathrm{~h}$ and subsequently weighed to estimate the yield in each treatment.

Water use efficiency (WUE) was determined as a function of cowpea grain yield, calculated as the ratio between grain yield and total water depth used in each treatment, according to Souza et al. (2011), with values expressed in $\mathrm{kg} \mathrm{ha}^{-1} \mathrm{~mm}^{-1}$. Yield and WUE data were subjected to regression analysis and the significances of the generated equations were checked based on $\mathrm{F}$ test, considering them as valid if above 0.05 probability, as in the studies of Bastos et al. (2012) and Silva et al. (2017).

\section{Results AND Discussion}

During the experiment of 2014, there were mean temperatures of $28.1{ }^{\circ} \mathrm{C}$, a total rainfall of $158 \mathrm{~mm}$ and mean relative humidity of $82.2 \%$. The experiment of 2015 was influenced by the climate phenomenon of El Niño (Grimm, 2015 ) with reduction of rains along the cycle. The mean air temperature during the experimental period of 2015 was $28.0^{\circ} \mathrm{C}$, with relative humidity of $74.7 \%$ and total rainfall of $30 \mathrm{~mm}$ due to the lower cloud cover.

In the experiment of 2016, there were mean temperatures of $27.3{ }^{\circ} \mathrm{C}$, with total rainfall of $153 \mathrm{~mm}$ and mean relative humidity of $73.8 \%$.

Thus, it can be noted that the meteorological conditions between the experimental years were similar, since the experiment was repeated in the same period of the year (September to November), except for the rainfall regime, which reduced the water supply in 2015 .

The total water depths for each treatment in the three years of experiment are presented in Table 2. According to Bastos et al. (2008), depending on the cultivar, soil characteristics and local edaphoclimatic conditions, the cowpea crop needs 300 to $450 \mathrm{~mm}$ of water during the entire cycle.

For the cultivar adopted and region studied, the total water consumption is approximately $267.7 \pm 10.2 \mathrm{~mm}$ (Farias et al., 2017). Considering the total water depths supplied, it can be noted that in all years cowpea underwent increasing cumulative deficits from the treatment $50 \% \mathrm{ETc}$, which were the responsible for the reductions observed in the yield (Table 2).

Due to the reduction in rainfall events during the reproductive stage, from 36 DAS, it was possible to note

Table 2. Total water depths in vegetative and reproductive stages and in the cycle $(\mathrm{mm})$, yield $\left(\mathrm{kg} \mathrm{ha}^{-1}\right)$ and cumulative water deficit $(\mathrm{mm})$ in each treatment in the 3 years of experiment

\begin{tabular}{|c|c|c|c|c|c|c|c|c|}
\hline \multirow{2}{*}{ Years } & \multirow{2}{*}{ Treatments } & \multicolumn{2}{|c|}{ Vegetative } & \multicolumn{2}{|c|}{ Reproductive } & \multirow{2}{*}{$\begin{array}{l}\text { Total water } \\
\text { depth }(\mathrm{mm})\end{array}$} & \multirow{2}{*}{$\begin{array}{l}\text { Productivity } \\
\left(\mathrm{kg} \mathrm{ha}^{-1}\right)\end{array}$} & \multirow{2}{*}{$\begin{array}{l}\text { Accumulated water } \\
\text { deficit (DEF) (mm)* }\end{array}$} \\
\hline & & Irrigation & Rain & Irrigation & Rain & & & \\
\hline \multirow{4}{*}{2014} & $100 \%$ ETc & \multirow{4}{*}{75.6} & \multirow{4}{*}{108.2} & 93.9 & \multirow{4}{*}{50.3} & 328.0 & 1569.2 & 1.4 \\
\hline & $50 \%$ ETC & & & 46.9 & & 281.0 & 1233.5 & 7.0 \\
\hline & 25\%ETC & & & 23.5 & & 257.6 & 1002.3 & 17.0 \\
\hline & $0 \% \mathrm{ETC}$ & & & 0 & & 234.1 & 792.3 & 29.0 \\
\hline \multirow{4}{*}{2015} & $100 \%$ ETc & \multirow{4}{*}{173.8} & \multirow{4}{*}{0} & 113.5 & \multirow{3}{*}{30.5} & 317.8 & 1474.1 & 0 \\
\hline & $50 \%$ ETc & & & 56.7 & & 261.0 & 1098.0 & 30.2 \\
\hline & $25 \%$ ETc & & & 28.4 & & 232.7 & 943.9 & 57.7 \\
\hline & $0 \% \mathrm{ETC}$ & & & 0 & - & 173.8 & 468.3 & 112.5 \\
\hline \multirow{4}{*}{2016} & $100 \%$ ETc & \multirow{4}{*}{87.6} & \multirow{4}{*}{141.2} & 113.8 & \multirow{3}{*}{12.2} & 354.8 & 1597.1 & 0 \\
\hline & $50 \% \mathrm{ETC}$ & & & 56.9 & & 297.9 & 1295.3 & 33.1 \\
\hline & $25 \%$ ETc & & & 28.4 & & 269.4 & 1069.8 & 59.0 \\
\hline & $0 \% \mathrm{ETC}$ & & & 0 & - & 228.8 & 684.3 & 94.5 \\
\hline
\end{tabular}

${ }^{*} \mathrm{DEF}$ - Obtained by the difference between daily ETc and ETr calculated from sequential water balance of Thorntwaite and Matter, applied to a water daily incoming (rain + irrigation) and according to the evolution of the available water capacity (AWC) 
gradients in soil moisture content between the treatments because of a more efficient control in the deficit irrigation (Figure 1). Only in the experiment of 2014, soil moisture during the reproductive stage remained between field capacity (FC) and permanent wilting point (PWP), reaching however the limit of easily available water (EAW) at different moments.

In 2014, the EAW was reached at 51 and 55 DAS in the treatments 0 and 25\%ETc, respectively (Figure 1A) and earlier in 2015 , at 40 DAS in the treatment $0 \% \mathrm{ETc}$, at $46 \mathrm{DAS}$ in $25 \%$ ETc and at 56 DAS in 50\%ETc (Figure 1B).

In the experiment of 2016, the critical moisture was reached by the treatment $0 \% \mathrm{ETc}$ at $45 \mathrm{DAS}$, consuming water reserves of the soil close to 50 DAS when it reached the PWP. The other treatments subjected cowpea to different levels of water availability due to the irrigation depths applied in the reproductive stage. The difference found in the soil

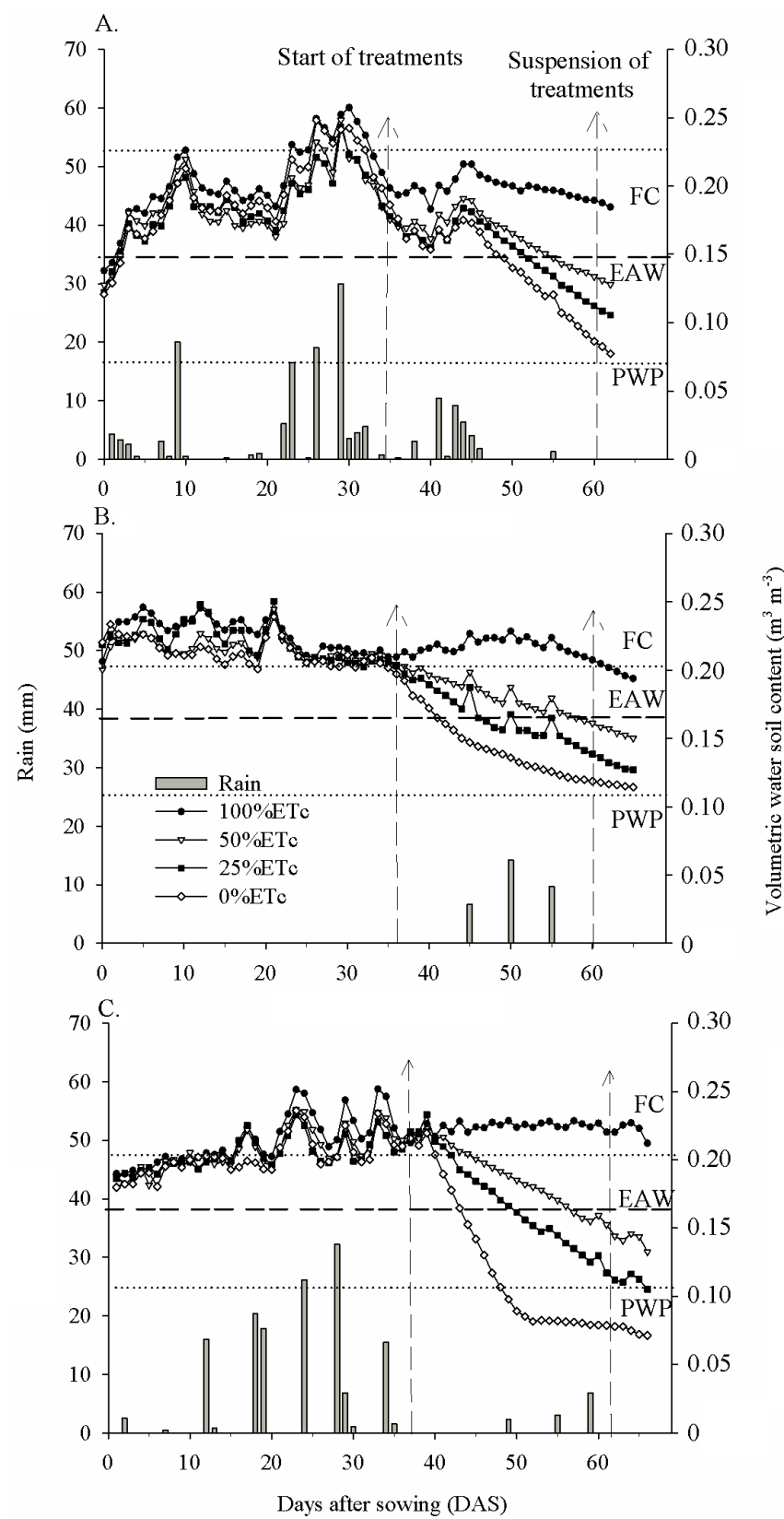

Figure 1. Rainfall, soil moisture, field capacity (FC), easily available water (EAW), permanent wilting point (PWP) and period in which treatments began in the experiments of 2014 (A), 2015 (B) and 2016 (C) in Castanhal, PA, Brazil water regime is a consequence of the characteristics of the experimental area used in the three years, since there was change in the 2015/2016 year due to logistic reasons, besides of course the rainfall regime observed in each experiment.

In a study with the cowpea cultivars BRS Paraguaçu and BRS Guariba subjected to different water regimes in the soil, Bastos et al. (2012) found significant reductions of yield at levels lower than $54 \%$ of available water in the soil at the end of the cycle as a function of the treatments.

In the three years of experiment, the data of grain yield fitted to a quadratic polynomial regression in response to the different water depths analyzed (Figure 2), a response pattern similar to that obtained by Andrade Junior et al. (2002) (BR 17 Gurguéia and BR 14 Mulato) and by Bastos et al. (2012) for green grains of cowpea (BRS Guariba and BRS Paraguaçu) in Piauí, by Azevedo et al. (2011) in Ceará (black bean) and by Locatelli et al. (2014) in Roraima (BRS Guariba and BRS Novaera).

Other authors have already observed a sigmoid pattern for the cultivar Pujante under Brazilian semi-arid conditions (Souza et al., 2011). However, regardless of the patterns fitted, there is a natural trend of increase in yield with greater water supply.

Highest yields $\left(1,569.2 ; 1,474\right.$ and $\left.1,596.5 \mathrm{~kg} \mathrm{ha}^{-1}\right)$ were obtained in response to the treatment $\mathrm{T} 1(100 \% \mathrm{ETc})$ in all years, respectively, for 2014, 2015 and 2016, and these values are much higher than the state average $\left(850 \mathrm{~kg} \mathrm{ha}^{-1}\right)$, demonstrating the production efficiency of the cultivar in the studied region if subjected to irrigation in possible additional seasons.

Bastos et al. (2011) analyzed the response of 20 cowpea genotypes to water supply and found maximum yields ranging from 613 to $1.529 \mathrm{~kg} \mathrm{ha}^{-1}$, indicating the importance of the cultivar to be adopted and its tolerance to water deficit. The use of maximum irrigation ( $100 \% \mathrm{ETc}$ ) led to increments of 49.5 , 68.2 and $57.1 \%$ in grain yield, respectively, for 2014, 2015 and 2016 , compared to the yields obtained in the treatment $0 \% \mathrm{ETc}$ (792.3; 468 and $\left.684.3 \mathrm{~kg} \mathrm{ha}^{-1}\right)$.

When subjected to water depths below $260 \mathrm{~mm}$, the cowpea crop (cultivar BR3-Tracuateua) tends to show mean yield lower

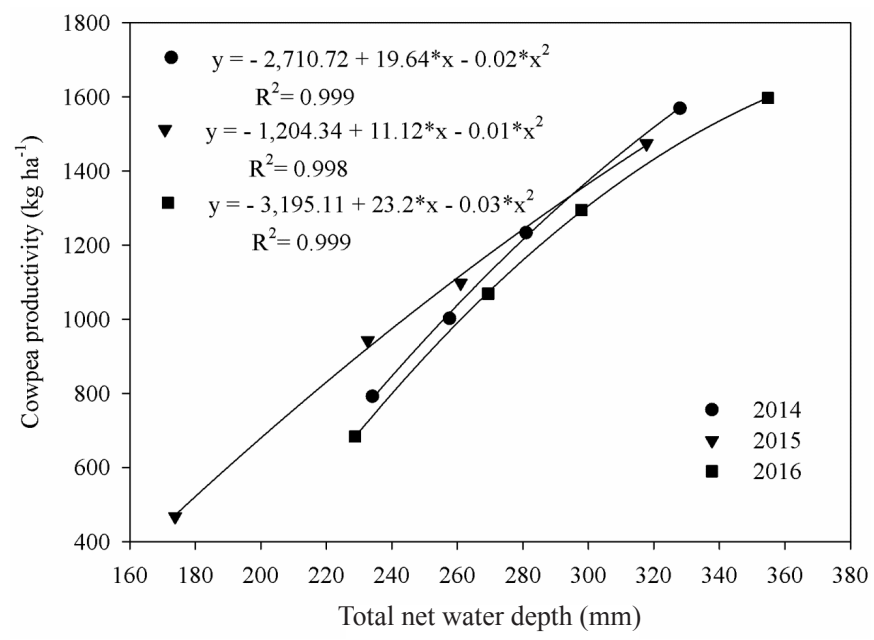

* Significant at 0.05 probability level by $\mathrm{F}$ test

Figure 2. Yield of dry grains as a function total water depths applied (mm) in the treatments T1 (100\%ETc), T2 (50\%ETc), T3 $(25 \% \mathrm{ETc})$ and T4 (0\%ETc) in the years of $2014(\bullet), 2015(\boldsymbol{\nabla})$ and 2016 (घ) 
than $1,000 \mathrm{~kg} \mathrm{ha}^{-1}$ in the studied region (Figure 2), since its total water demand is approximately $267.7 \mathrm{~mm}$ (Farias et al., 2017).

These results are similar to those obtained by Souza et al. (2011) and Dutra et al. (2015), who observed that the production components of the studied cowpea cultivars were better expressed with water depths equivalent to $100 \%$ ETo. According to Silva et al. (2010), the presence of water deficit precludes several physiological and metabolic processes in cowpea, reducing its yield, because water is one of the main factors responsible for regulating the stomata.

The values of water use efficiency in the three years for maximum grain yield corresponded to, respectively, for 2014, 2015 and 2016, 4.8, 4.6 and $4.5 \mathrm{~kg} \mathrm{ha}^{-1} \mathrm{~mm}^{-1}$ and were obtained, respectively, with the application of irrigation depths of 328.1, 317.8 and $354.8 \mathrm{~mm}$, in the treatment $100 \%$ ETc (Figure 3), which were the ones leading to highest production.

Maximum water supply led to mean WUE of $4.63 \mathrm{~kg} \mathrm{ha}^{-1} \mathrm{~mm}^{-1}$, for the cultivar BR3 Tracuateua in the studied region, which is higher than that obtained for the cultivar Pujante in other regions, according to the results reported by Souza et al. (2011), who found maximum water use efficiency of $3.12 \mathrm{~kg} \mathrm{ha}^{-1} \mathrm{~mm}^{-1}$ with an irrigation depth of $421 \mathrm{~mm}$.

The water depths applied in the treatment 50\%ETc (mean of $280 \mathrm{~mm}$ ), however, allowed for mean water use efficiency of $4.31 \mathrm{~kg} \mathrm{ha}^{-1} \mathrm{~mm}^{-1}$ (4.39 in 2014, 4.2 in 2015 and 4.35 in 2016), only $6 \%$ lower than that obtained under optimal water conditions, with mean supply of $333 \mathrm{~mm}$ (Table 2), which demonstrates that it is feasible to use lower water depth during the reproductive stage, instead of maximum water depth.

Although the treatment $100 \%$ ETc produced on average $338 \mathrm{~kg} \mathrm{ha}^{-1}$ more than the treatment 50\%ETc (Table 2), the small difference in cowpea water use efficiency in both conditions may have occurred because, along the reproductive stage, the soil water content in the treatment 50\%ETc remained within the limit of easily available water (Figure 1), causing a mean water deficit of only $23 \mathrm{~mm}$ (Table 2), which may have allowed stomata to remain open even in the presence of a mild water deficit (Souza et al., 2017).

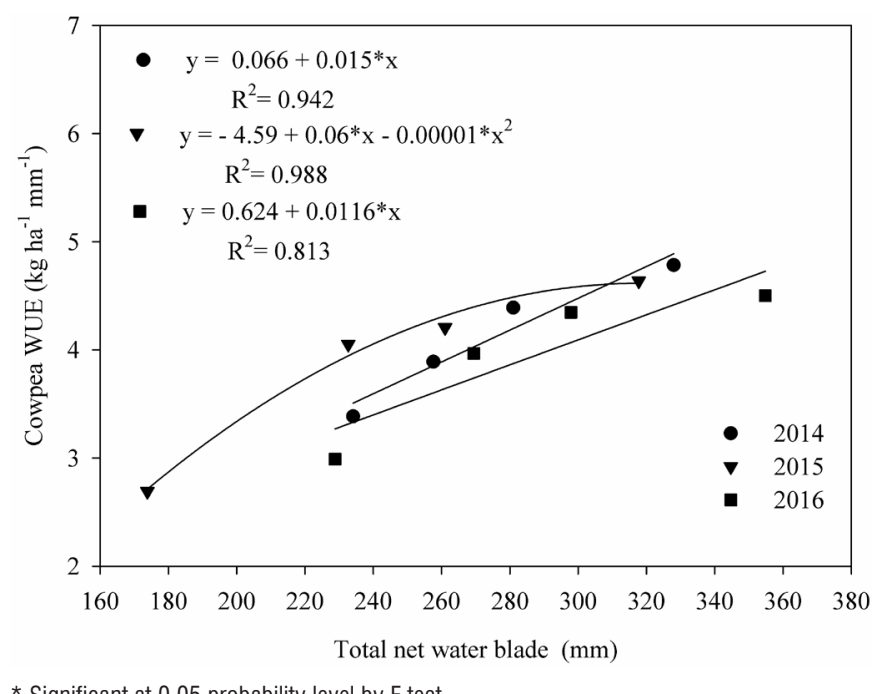

* Significant at 0.05 probability level by $\mathrm{F}$ test

Figure 3. Water use efficiency as a function of total water depths applied in the treatments T1 (100\%ETc), T2 (50\%ETc), T3 (25\%ETc) and T4 (0\%ETc) in the years of $2014(\bullet), 2015(\boldsymbol{\nabla})$ and 2016 (घ)
It is possible to note a probable trend of reduction in water use efficiency to values higher than the water supply corresponding to treatment $100 \% \mathrm{ETc}$, although water depths above the maximum requirement of the crop were not adopted. This pattern of reduction was also observed by Souza et al. (2011), who subjected cowpea to water depth of $125 \% \mathrm{ETc}$, and the best water use efficiency obtained by these authors corresponded to the water depth of $75 \%$ ETo, equal to $3.13 \mathrm{~kg} \mathrm{ha}^{-1} \mathrm{~mm}^{-1}$ for cowpea in single cultivation (total water depth of $421 \mathrm{~mm}$ ) and $1.31 \mathrm{~kg} \mathrm{ha}^{-1} \mathrm{~mm}^{-1}$ for cowpea intercropped with corn (total water depth of $443 \mathrm{~mm}$ ).

It can be noted that cowpea reduces its water use efficiency when subjected to limited water conditions, indicating its low tolerance to the lack of water, which corroborates other results that demonstrate the existence of a strategy in some plants to use water efficiently in order to increase their production $(\mathrm{Wu}$ et al., 2008).

Other studies, however, have found contrary results, with improvement in the WUE of some ornamental species under water deficit conditions due to possible acclimation to the lack of water, related to an efficient adaptation of the stomatal control over photosynthesis, maintaining $\mathrm{CO}_{2}$ assimilation proportionally higher than the loss of water by the stomata (Álvarez et al., 2011). When plants are subjected to water stress, there is a reduction in stomatal opening as a protective measure, and consequently a reduction in the $\mathrm{CO}_{2}$ influx in the substomatal chamber (Nascimento et al., 2011; Silva et al., 2017).

For the cultivar used in this study, some results showed that it does not tolerate water deficit, especially during the reproductive stage, with significant reductions in both stomatal conductance (Souza et al., 2017) and leaf water potential and production of assimilates (Nascimento et al., 2011), which justifies its reduction in water use efficiency when subjected to lower water supply.

Some authors observed, however, that cowpea can preserve leaf water potential (Freitas et al., 2017) and relative water content (Anyia \& Herzog, 2004) even under cumulative water deficit conditions, a characteristic also observed by Guimarães et al. (2006) for common beans, suggesting that the crop acts as a conservative species by prioritizing the maintenance of its water status rather than its photosynthetic activity, corroborating the reduction found in its WUE in the presence of water deficit.

However, a future analysis of economic efficiency is necessary to define the ideal water depth to be supplied through irrigation in possible additional seasons. The results of Silva et al. (2016) showed that the yield of irrigated cowpea in the Apodi region, Rio Grande do Norte, was $34.4 \%$ higher than that under rainfed conditions, and the use of this management was economically viable, since the net income was $37 \%$ higher than that of rainfed cowpea. Castro Junior et al. (2015) also concluded that the production of cowpea irrigated by conventional sprinkler in the region of Cocais, Maranhão, is economically viable even during the period with lower water supply.

These results can be used as a basis in the search for a second or even a third season of cowpea in the producing regions of the 
Pará state, considering that the irrigation management, guided by the demands of the crop and its efficient use of water, allows for economic gains and advance in the local production chain.

\section{Conclusions}

1. The cowpea cultivar BR3 Tracuateua can reach maximum production efficiency, equal to $4.63 \mathrm{~kg} \mathrm{ha}^{-1} \mathrm{~mm}^{-1}$ of water supplied, always when its maximum water demand of $138 \mathrm{~mm}$ in the reproductive stage is met.

2. Water supplies below $260 \mathrm{~mm}$ in the cycle limit the mean yield of the cultivar BR3 Tracuateua to values lower than $1,000 \mathrm{~kg} \mathrm{ha}^{-1}$.

3. Irrigation depth equivalent to $50 \%$ of the water demand in the reproductive stage led to a water use efficiency similar to that obtained with irrigation depth of $100 \%$ and can be adopted in period and regions of the state where water is a limiting factor.

\section{ACKNowledgments}

To the National Council for Scientific and Technological Development (CNPq) for funding the research through the Universal project (Process $n^{\circ} 483402 / 2012-5$ ).

\section{Literature Cited}

Allen, R. G.; Pereira, L. S.; Howell, T. A.; Jenses, M. E. Evapotranspiration information reporting: I. Factors governing measurement accuracy. Agricultural Water Management, v.98, p.899-920, 2011. https://doi.org/10.1016/j.agwat.2010.12.015

Álvarez, S.; Navarro, A.; Nicolás, E.; Sánchez-Blanco, M. J. Transpiration, photosynthetic responses, tissue water relations and dry mass partitioning in Callistemon plants during drought conditions. Scientia Horticulturae, v.129, p.306-312, 2011. https:// doi.org/10.1016/j.scienta.2011.03.031

Andrade Junior, A. S.; Rodrigues, B. H. N.; Frizzone, J. A.; Cardoso, M. J.; Bastos, E. A.; Melo, F. B. Níveis de irrigação na cultura do feijãocaupi. Revista Brasileira Engenharia Agrícola e Ambiental, v.6, p.17-20, 2002. https://doi.org/10.1590/S1415-43662002000100004

Anyia, A. O.; Herzog, H. Water-use efficiency, leaf area and leaf gas exchange of cowpeas under mid-season drought. European Journal of Agronomy, v.20, p.327-339, 2004. https://doi. org/10.1016/S1161-0301(03)00038-8

Azevedo, B. M.; Fernandes, C. N. V.; Pinheiro, J. A.; Braga, E. S.; Campêlo, A. R.; Viana, T. V. A.; Camboim Neto, L. F.; Marinho, A. B. Efeitos de lâminas de irrigação na cultura do feijão vigna de cor preta. Agropecuária Técnica, v.32, p.152-159, 2011.

Barros, M. A.; Rocha, M. M.; Gomes, R. L. F.; Silva, K. J. D.; Neves, A. C. Adaptabilidade e estabilidade produtiva de feijão-caupi de porte semiprostrado. Pesquisa Agropecuária Brasileira, v.48, p.403-410, 2013. https://doi.org/10.1590/S0100-204X2013000400008

Bastos, E. A.; Ferreira, V. M.; Silva, C. B.; Andrade Junior, A. S. Evapotranspiração e coeficiente de cultivo do feijão-caupi no Vale do Gurguéia, Piauí. Irriga, v.13, p.82-90, 2008.
Bastos, E. A.; Nascimento, S. P.; Silva, E. M.; Freire Filho, F. R.; Gomide, R. L. Identification of cowpea genotypes for drought tolerance. Revista Ciência Agronômica, v. 42, p.100-107, 2011. https://doi. org/10.1590/S1806-66902011000100013

Bastos, E. A.; Ramos, H. M. M.; Andrade Junior, A. S.; Nascimento, F. N.; Cardoso, M. J. Parâmetros fisiológicos e produtividade de grãos verdes do feijão-caupi sob déficit hídrico. Water Resources and Irrigation Management, v.1, p.31-37, 2012.

Calvet, A. S. F.; Pinto, C. M.; Maia-Joca, R. P. M.; Bezerra, A. crescimento e acumulação de solutos em feijão-de-corda irrigado com águas de salinidade crescente em diferentes fases de desenvolvimento. Irriga, v.18, p.148-159, 2013. https://doi. org/10.15809/irriga.2013v18n1p148

Carvalho, H. de P.; Dourado Neto, D.; Teodoro, R. E. F.; Melo, B. de. Balanço hídrico climatológico, armazenamento efetivo da água no solo e transpiração na cultura de café. Bioscience Journal, v.27, p.221-229, 2011.

Castro Junior, W. L.; Oliveira, R. A.; Silveira, S. F. R.; Andrade Junior, A. S. Viabilidade econômica de tecnologias de manejo da irrigação na produção do feijão-caupi, na região dos cocais-MA. Engenharia Agrícola, v.35, p.406-418, 2015. https://doi.org/10.1590/18094430-Eng.Agric.v35n3p406-418/2015

Dutra, A. F.; Melo, A. S. de; Filgueiras, L. M. B.; Silva, A. R. F.; Oliveira, I. M.; Brito, M. E. B. Parâmetros fisiológicos e componentes de produção de feijão-caupi cultivado sob deficiência hídrica. Revista Brasileira de Ciências Agrárias, v.10, p.189-197, 2015. https://doi. org/10.5039/agraria.v10i2a3912

Farias, V. D. S.; Costa, D. L. P.; Souza, P. J. O. P.; Takaki, A. Y.; Lima, M. J. A. Temperaturas basais e necessidade térmica para o ciclo de desenvolvimento do feijão-caupi. Enciclopédia Biosfera, v.11, p.1781-1792, 2015.

Farias, V. D. S.; Lima, M. J. A. de; Nunes, H. G. G. C.; Sousa, D. de P.; Souza, P. J. de O. P. de. Water demand, crop coefficient and uncoupling factor of cowpea in the eastern amazon. Revista Caatinga, v.30, p.190-200, 2017. https://doi.org/10.1590/198321252017v30n121rc

Freire Filho, F. R.; Cravo, M. S.; Ribeiro, V. Q.; Rocha, M. M.; Castelo, E. O.; Brandão, E. S.; Belmino, C. S.; Melo, M. I. S. BRS Milênio e BRS Urubuquara: Cultivares de feijão-caupi para a região Bragantina do Pará. Revista Ceres, v.56, p.749-752, 2009.

Freire Filho, F. R.; Ribeiro, V. Q.; Rocha, M. M.; Silva, K. J. D.; Nogueira, M. S. R.; Rodrigues, E. V. Feijão-caupi no Brasil: Produção, melhoramento genético, avanços e desafios. 1.ed. Teresina: Embrapa Meio-Norte, 2011. 84p.

Freitas, R. M. O.; Dombroski, J. L. D.; Freitas, F. C. L.; Nogueira, N. W.; Pinto, J. R. S. Physiological responses of cowpea under water stress and rewatering in no-tillage and conventional tillage systems. Revista Caatinga, v.30, p.559-567, 2017. https://doi. org/10.1590/1983-21252017v30n303rc

Grimm, A. M. El niño, novamente! Revista Brasileira de Meteorologia, v.30, p.351-357, 2015. https://doi.org/10.1590/0102-778620152000

Guimarães, C. M.; Stone, L. F.; Brunini, O. Adaptação do feijoeiro comum (Phaseolus vulgaris L.) à seca. Revista Brasileira de Engenharia Agrícola e Ambiental, v.10, p.70-75, 2006. https:// doi.org/10.1590/S1415-43662006000100011

Locatelli, V. E. R.; Medeiros, R. D.; Smiderle, O. J.; Albuquerque, J. A. A.; Araújo, W. F. Desenvolvimento vegetativo de cultivares de feijãocaupi sob lâminas de irrigação no cerrado roraimense. Irriga, v.1, p.28-39, 2016. https://doi.org/10.15809/irriga.2016v1n1p28-39 
Nascimento, S. P.; Bastos, E. A.; Araújo, E. C. E.; Freire Filho, F. R.; Silva, E. M. Tolerância ao déficit hídrico em genótipos de feijão-caupi. Revista Brasileira de Engenharia Agrícola e Ambiental, v.15, p.853-860, 2011. https://doi.org/10.1590/S141543662011000800013

Oliveira, G. A.; Araújo, W. F.; Cruz, P. L. S.; Silva, W. L. M.; Ferreira, G. B. Resposta do feijão-caupi as lâminas de irrigação e as doses de fósforo no cerrado de Roraima. Revista Ciência Agronômica, v.42, p.872-882, 2011. https://doi.org/10.1590/ S1806-66902011000400008

Scalon, S. P. Q.; Mussury, R. M.; Euzébio, V. L. M.; Kodama, F. M.; Kissmann, C. Estresse hídrico no metabolismo e crescimento inicial de mudas de mutambo (Guazuma ulmifolia Lam.). Ciência Florestal, v.21, p.657-665, 2011. https://doi. org/10.5902/198050984510

Silva, C. D. S. e; Santos, P. A. A.; Lira, J. M. S.; Santana, M. C. de; Silva Júnior, C. D. da Curso diário das trocas gasosas em plantas de feijão-caupi submetidas a deficiência hídrica. Revista Caatinga, v.23, p.7-13, 2010.

Silva, V. P. R.; Silva, B. B.; Bezerra, J. R. C; Almeida, R. S. R. Consumo hídrico e viabilidade econômica da cultura do feijão caupi cultivado em clima semiárido. Irriga, v.21, p.662-672, 2016. https://doi.org/10.15809/irriga.2016v21n4p662-672
Silva, W. C.; Moura, J. G.; Oliveira, A. B.; Ferreira, L. E.; Silva, T. M. Growth and gas exchange in cowpea plants under different managements and saline conditions. Revista Ciência Agronômica, v.48, p.756-764, 2017. https://doi.org/10.5935/18066690.20170088

Souza, L. S. B.; Moura, M. S. B.; Sediyama, G. C.; Silva, T. G. F. Eficiência do uso da água das culturas do milho e do feijãocaupi sob sistemas de plantio exclusivo e consorciado no semiárido brasileiro. Bragantia, v.70, p.715-721, 2011. https:// doi.org/10.1590/S0006-87052011000300030

Souza, P. J. O. P.; Lima, M. J. A.; Farias, V. D. S.; Ramos, T. F.; Sousa, A. M. L. Biomass and leaf area production and yield of cowpea under water regimes in Castanhal, Pará. Revista Caatinga, v.30, p.748759, 2017. https://doi.org/10.1590/1983-21252017v30n323rc

Teixeira, W. G.; Behring, S. B. Retenção de água no solo pelos métodos da mesa de tensão e da câmara de Richards. In: Teixeira, P. C.; Donagemma, G. K.; Fontana, A.; Teixeira, W. G. (eds.). Manual de métodos de análise de solo. 3.ed. rev. ampl. Brasília: Embrapa Informação Tecnológica, 2017. p.34-46.

Wu, F.; Bao, W.; Li, F.; Wu, N. Effects of drought stress and N supply on the growth, biomass partitioning and water-use efficiency of Sophora davidii seedlings. Environmental and Experimental Botany, v.63, p.248-255, 2008. https://doi.org/10.1016/j.envexpbot.2007.11.002 